\title{
Application of Moringa (Moringa oleifera) as Natural Feed Supplement in Poultry Diets
}

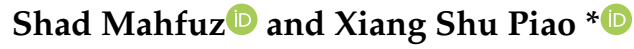 \\ State Key laboratory of Animal Nutrition, College of Animal Science and Technology, China Agricultural \\ University, Beijing 100193, China \\ * Correspondence: piaoxsh@cau.edu.cn; Tel./Fax: +86-1062733688
}

Received: 30 May 2019; Accepted: 28 June 2019; Published: 9 July 2019

Simple Summary: The wide application of in-feed antibiotics in poultry production has created public health hazards. A driving force for the interest of using natural herbs is to establish the antibiotics alternative in poultry production that has been reported in the literature. Therefore, the objective of the current review is to determine the effects of moringa (Moringa oleifera) tree leaves, seeds and their extracts on chickens' performance and health status. Based on previous findings, M. oleifera as natural feed supplement has sustained the production performance and improved the health status in chickens.

\begin{abstract}
Application of natural herbs with a view to enhancing production performance and health status has created an important demand in poultry production. With the increasing concerns on this issue, greater attention paid to alternatives to antibiotics for organic meat and egg production has led to a great demand. This study was conducted with view to assessing the possible role of M. oleifera as a natural feed supplement in poultry ration. Various scientific findings and published research articles were considered concerning issues including the study background, objectives, major findings, and conclusions of the review. M oleifera is known as a miracle tree because of its wealthy resource of various nutrients with high biological values. M. oleifera has been used as a growth promoter, immune enhancer, antioxidant, and has a hypo-cholesterol effect on chickens. It has both nutritional and therapeutic values. However, there is still much confusion in past published articles involving the major roles of $M$. oleifera in production performance and health status of chickens. Taking this into account, the present study highlights an outline of the experimental uses of M. oleifera on growth performance, egg production performance, egg quality, and health status in broilers and laying hens justified with the past findings to the present. The knowledge gaps from the past studies are considered, and the feasibility of $M$. oleifera in poultry ration is suggested. The findings have motivated further study on M. oleifera to find out the most active ingredients and their optimal doses in both broiler and laying hen rations. Finally, the present study highlights that supplementation of M. oleifera may play a role in the immunity, sound health, and production performance in poultry.
\end{abstract}

Keywords: Moringa oleifera; poultry; growth performance; laying performance; health status

\section{Introduction}

The human population is increasing globally day by day. Meeting the increasing demand of animal protein and providing safe food for human beings that is free from antibiotics by using herbal feed resources is a great challenge for the animal scientists in the future. The issue considering antibiotic resistance has created an augmented force to reduce antibiotic uses in livestock and poultry production [1,2]. Dietary inclusion of herbs and their extracts has growth-promoting roles in poultry [3]. Furthermore, different natural medicinal plants and their extracts as feed supplements have been 
used as a substitute for antibiotics in poultry production [4,5]. In addition, Mahfuz et al. [6] reported that poultry scientists are now dedicated to applying unconventional natural feed supplement, which may play a role in possible therapies to improve the health as well as production performance of chickens.Thus, poultry researchers are searching for potential natural feed resources that will be both environmentally friendly and safe for human society $[7,8]$.

Moringa oleifera is a well-known cultivated species in the genus Moringa, (family Moringaceae) under the order Brassicales. The common names of Moringa oleifera include moringa, drumstick tree, horseradish tree, and ben oil tree or benzoil tree or miracle tree [9-11]. The M. oleifera tree is native to South Asia, especially India, Sri Lanka, Pakistan, Bangladesh, Afghanistan; North Eastern and South Western Africa, Madagascar, and Arabia [12-15]. The moringa seed and leaves have a broad use in the food industry and therapeutic issues [12]. It is popular for its seeds, flowers and leaves inhuman food and as herbal medicine [16]. The different parts of the M. oleifera tree are used as a good source of human nutrition and in traditional diets in different countries of the world $[17,18]$. Furthermore, the seed powder of $M$. oleifera contains polyelectrolytes, which are the most important active ingredients for water purification $[18,19]$.

Moringa oleifera is very useful as a feed supplement for animals, as its leaves are highly nutritious. The leaves of M. oleifera are the most nutritious part, being a significant source of vitaminB complex, vitamin C, pro-vitamin A as beta-carotene, vitamin $\mathrm{K}$, manganese, and protein among other essential nutrients [20]. Moringa oleifera leaves have antimicrobial roles and are rich with fats, proteins, vitamins, and minerals $[18,21]$. The extracts from leaves of Moringa oleifera contain low amounts of polyphenols, which might have effects on blood lipid metabolism [20,22]. Moringa oleifera can be used as a source of micronutrient and as a dietary supplement in poultry $[23,24]$. In addition, Moringa oleifera leaf powder has anti-septic and detergent properties due to presence of different phytochemicalsin the leaves [25]. Moringa oleifera was reported to be an excellent source of vitamins and amino acids that reportedly boost immune systems [17]. The seed extracts of moringa are rich in polyunsaturated fatty acid [26,27]. Moringa oleifera exhibits anti-oxidant properties that can suppress formation of reactive oxygen species (ROS) and free radicals [27,28].

Until the present day, the application of M. oleifera in farm animals to improve the production performance and health status has been limited. Even though it was established that $M$. oleifera has medicinal importance for the health of chickens, unfortunately the inclusion levels of M. oleifera in poultry ration and their mode of actions are still under consideration. Taking this into consideration, the present study focuses on uses of M. oleifera as a natural feed supplement as well as an alternative to antibiotics that can improve the performance and health status of chickens.

\section{Biological Role of M. oleifera}

The M. oleifera tree is globally known for its economic and therapeutic roles (Figure 1). Ithas been honored as the "Botanical of the Year 2007" by the National Institute of Health (USA), [11]. The tree is also known as "never die" or "miracle tree"to the people of Africa [11]. Now the application of M. oleifera leaves in preparing foods is receiving great attention. Peoples from Ghana, Nigeria, Ethiopia, East Africa, and Malawi are consuming the moringa tree leaves directly in their diets [29]. Furthermore, M. oleifera leaves have been used for making soups, foods, breads, cakes, and yoghurts [30-33]. 

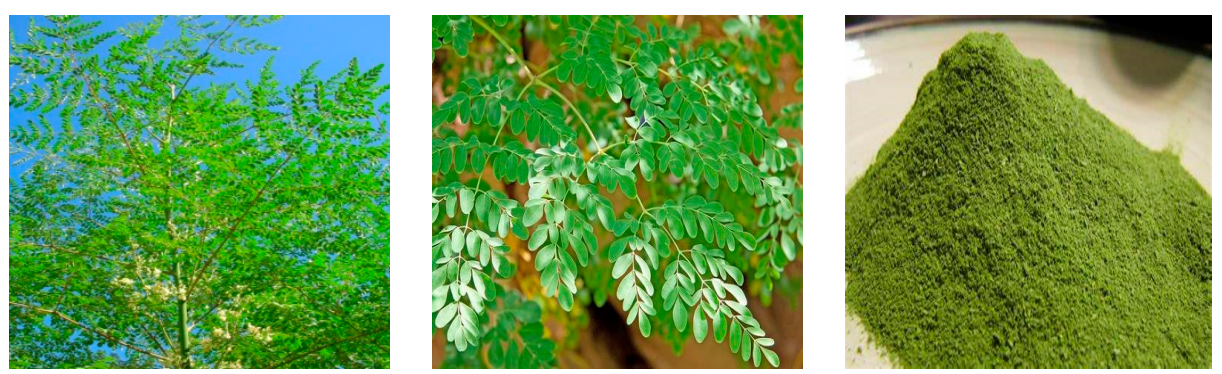

Figure 1. Moringa oleifera tree, tree leaves, and leaves powder.

\subsection{Antioxidant Properties of M.oleifera}

M. oleifera tree leaves possess various phytochemicals that have antioxidant properties and roles in controlling a wide range of diseases, like diarrhea, asthma, and various cancers [11]. The leaves of $M$. oleifera have also been reported to hold extensive amounts of total phenols, proteins, calcium, potassium, magnesium, iron, manganese, and copper [33]. They also contain rich sources of different phytonutrients, such as carotenoids, tocopherols, and ascorbic acid, which are good sources of dietary antioxidants [34,35]. A significant increase in activities of superoxide dismutase (SOD), catalase (CAT), glutathione-S-transferase (GST), and a decrease in lipid peroxide (LPS) content were found in moringa leaf extracts [11]. In addition, leaves extract from M. oleifera could improve the superoxide dismutase (SOD), catalase, glutathione, and peroxidase levels and reduce lipid peroxidation in albino mice [36]. Furthermore, total phenolic, flavonoid, and flavonol content in leaf extracts was found to be $120 \mathrm{mg} / \mathrm{g}$ of gallic acid equivalents (GAE), $40 \mathrm{mg} / \mathrm{g}$ of GAE, and $12.12 \mathrm{mg} / \mathrm{g}$ of GAE, respectively [37,38].

\subsection{Therapeutic and Antimicrobial Properties of M.oleifera}

M. oleifera leaf extracts have been distinguished as having anticancer, cytotoxic, anti-proliferative, anti-leukemia, anti-hepatocarcinoma, and chemo-protective properties [39-41]. The antitumor function of leaf extracts of $M$. oleifera is associated with the antioxidant and apoptosis inducing properties [42,43]. The antimicrobial properties of M. oleifera are well established. The extracts derived from M. oleifera tree leaves have been reported to be potential antibacterial and antifungal functions against various bacterial and fungal species [11,44,45]. Oluduro et al. [46] and Pandey et al. [47] have highlighted that M. oleifera exhibited 4-( $\alpha$-L-rhamnopyranosyloxy) benzyl isothiocyanate, methyl N-4-( $\alpha$-Lrhamnopyranosyloxy) benzyl carbamate, and 4-( $\alpha$-D-glucopyranosyl-1 $\rightarrow 4-\alpha$-L-rhamnopyranosyloxy) benzyl thiocarboxamide that were able to play antimicrobial properties. The antimicrobial activities of the Moringa oleifera may be due to presence of lipophilic compounds and different metabolites (carboxylic acid, 2,4-diacetyl phloroglucinol, enzymes, and chitinases) in plant cell walls [48].

\subsection{Immune Stimulating and Hypocholesterolemic Properties of M.oleifera}

The immune functions of $M$. oleifera are also established by several in vitro studies [11]. Various biochemical ingredients, like quercetin, different glycosides, various isothiocyanate, kaempferol glucosides, that possess anti-inflammatory properties have been demonstrated from the extract of various parts of M. oleifera [49,50]. Different protein and various peptides' (isothiocyanates, glycoside cyanides etc.) presences in $M$. oleifera leaf extracts were able to modify the immune response positively [51,52]. An investigation was carried out to detect the immunomodulatory activity of M. oleifera on mice model. Chronic administration of M. oleifera significantly increased white blood cell (WBC) count and percent of neutrophils in experimental mice [51]. The exact mechanism of action of moringa leaves on stimulating the humoral and cellular immunity is not clear yet [51]. M. oleifera leaf extracts are reported to possess ahypo-cholesterolemic function [53]. $\beta$-sitosterol and 4-[ $\alpha$-(L-rhamnosyloxy) benzyl]-o-methyl thiocarbamate (trans) are two important active substances presence in the leaf extracts of $M$. oleifera that exhibit cholesterol lowering activities. These compounds could reduce the intestine uptake of dietary cholesterol in rats [49,54]. Furthermore, plasma cholesterol 
was decreased and fecal cholesterol was increased in rats fed with moringa leaf extracts $[49,53]$. In addition, another two components, moringine and moringinine, have been recently identified from M. oleifera leaves, which have roles in anti-hypoglycemic functions [49,55].

\subsection{Nutritional Properties of M.oleifera}

M. oleifera is also very popular for its nutritional values. It is reported as a good source of six major nutrients: Carbohydrate, especially dietary fibers; proteins; vitamins; minerals; lipids; and water. The unique features of $M$. oleifera are its richness in proteins, carbohydrates, and fibers with low fat. The leaves have been reported to enclose a range of essential amino acids and are a good source of alpha linoleic acid [56]. M. oleifera leaves have been seen to exhibit high contents of vitamin A, C, and $E$ [33]. The relative bioavailability of folate originated from M. oleifera leaves were about $82 \%$ in a rat model, which confirmed the fact that $M$. oleifera leaves exhibit rich source of dietary folate [57].

The nutritional composition of $M$. oleifera leaves (dry matter basic) showed dry matter (DM) about $93.63 \%$ to $95.0 \%$, crude protein (CP) $17.01 \%$ to $22.23 \%$, carbohydrate $63.11 \%$ to $69.40 \%$, crude fiber (CF) $6.77 \%$ to $21.09 \%$, crude fat (EE) $2.11 \%$ to $6.41 \%$, ash (total mineral) $7.96 \%$ to $8.40 \%$, gross energy $14.790(\mathrm{MJ} / \mathrm{kg}$ ), and fatty acid $1.69 \%$ to $2.31 \%$ [58-60]. In addition, estimated calcium (Ca) was $1.91 \%$; potassium $(\mathrm{K})$ was $0.97 \%$; sodium $(\mathrm{Na})$ was 192.95 , iron was $(\mathrm{Fe}) 107.48$, manganese $(\mathrm{Mn})$ was 81.65 , Zinc (Zn) was 60.06, and phosphorus (P) was 30.15 parts per million (ppm) [59]. Magnesium (Mg) was $0.38 \%$, and copper $(\mathrm{Cu})$ was $6.1 \%$, tannins $21.19 \%$, phytates $2.57 \%$, trypsin inhibitors $3.0 \%$, saponins $1.60 \%$, oxalates $0.45 \%$, and cyanide $0.1 \%$ was also reported by Ogbe and John [59]. The leaves of the plant are enriched with methionine, phosphorus, calcium, and iron [11]. It is believed that the leaves of M. oleifera contain more calcium and twice as much protein than milk, higher vitamin $C$ than oranges, higher potassium and iron than bananas, and higher vitamin A than carrots [10,61], and thus the plant is considered unique in nature [62]. Niaziridin, an active component that was identified from M. oleifera, can improve the absorption of different vitamins, minerals, and other micro nutrients in gastrointestinal tract of the host [50]. The nutritional composition of M. oleifera leaves are presented in Tables 1 and 2.

Table 1. Chemical compositions of Moringa oleifera leaves ${ }^{\dagger}$.

\begin{tabular}{cccc}
\hline Nutrient Component & Fresh Leaves & Dry Leaves & Leaves Powder \\
\hline Calories $(\mathrm{cal})$ & 92 & 329 & 205 \\
Protein $(\mathrm{g})$ & $6.7-17.1$ & $29.4-40.0$ & $25.4-27.1$ \\
Fat $(\mathrm{g})$ & $1.7-2.11$ & $5.2-6.5$ & 2.3 \\
Carbohydrate $(\mathrm{g})$ & $6.3-12.5$ & $38.0-41.2$ & $34.3-38.2$ \\
Fiber $(\mathrm{g})$ & $0.9-7.09$ & $12.5-21.09$ & 19.2 \\
Vitamin A & $0.9-11.05$ & $16.3-18.90$ & - \\
Vitamin B1 (mg) & 0.06 & $2.02-2.60$ & 2.64 \\
Vitamin B2 $(\mathrm{mg})$ & 0.05 & $19.82-21.3$ & 20.5 \\
Vitamin B3 $(\mathrm{mg})$ & 0.8 & $7.6-8.3$ & 8.2 \\
Vitamin C $(\mathrm{mg})$ & 220 & $15.8-17.3$ & 17.3 \\
Vitamin E $(\mathrm{mg})$ & 448 & $10.8-77.0$ & 113 \\
Calcium $(\mathrm{mg})$ & 440 & $2185-3050$ & 2003 \\
Magnesium $(\mathrm{mg})$ & $42-82$ & $86-448$ & 368 \\
Phosphorus $(\mathrm{mg})$ & $30.15-70$ & $204-252$ & 204 \\
Potassium $(\mathrm{mg})$ & 259 & $1236-1384$ & 1324 \\
Copper $(\mathrm{mg})$ & 0.07 & $0.08-0.49$ & 0.57 \\
Iron $(\mathrm{mg})$ & $0.85-10.7$ & $25.6-490$ & 870 \\
Sulphur $(\mathrm{mg})$ & - & $363-630$ & - \\
Zinc $(\mathrm{mg})$ & 6.7 & $3.25-13.03$ & - \\
Manganese $(\mathrm{mg})$ & 81.6 & $86.8-91.2$ & \\
\hline${ }^{\dagger}$ All values are in $100 \mathrm{~g}$ per plant material. References: & &
\end{tabular}


Table 2. Amino acid contents in Moringa oleifera leaves ${ }^{\dagger}$.

\begin{tabular}{|c|c|c|}
\hline Amino Acid & Fresh Leaves (mg g $\left.{ }^{-1} \mathrm{DM}\right)$ & Extracted Leaves $\left(\mathrm{mg} \mathrm{g}^{-1} \mathrm{DM}\right)$ \\
\hline Lysine & $13.25-26.77$ & $14.06-18.09$ \\
\hline Leucine & $20.52-42.89$ & $17.5-21.84$ \\
\hline Isoleucine & $11.91-22.53$ & $8.08-11.30$ \\
\hline Methionine & $3.5-8.96$ & $1.13-4.97$ \\
\hline Cystine & $3.8-5.18$ & $1.0-3.39$ \\
\hline Phenylalanine & $16.31-27.14$ & $8.9-15.51$ \\
\hline Tyrosine & 18.88 & 9.71 \\
\hline Valine & $10.62-27.58$ & $7.25-14.26$ \\
\hline Histidine & $5.17-13.57$ & $7.16-7.50$ \\
\hline Threonine & $13.5-21.97$ & $7.90-11.70$ \\
\hline Serine & $10.87-20.79$ & $9.40-10.34$ \\
\hline Glutamic acid & $28.42-50.85$ & $17.10-25.65$ \\
\hline Aspartic acid & $20.52-46.11$ & $14.3-22.16$ \\
\hline Proline & $14.3-25.75$ & $12.41-13.63$ \\
\hline Glycine & $15.33-26.62$ & $10.3-13.73$ \\
\hline Alanine & $28.67-30.33$ & $12.51-18.37$ \\
\hline Arginine & $18.9-30.28$ & $13.25-15.64$ \\
\hline Tryptophan & $4.25-9.26$ & $5.27-7.16$ \\
\hline
\end{tabular}

${ }^{\dagger}$ References: $[15,56,64,65]$.

It was thought that the moringa contains different anti-nutritional factors, such as tannins, phytates, oxalates and cyanide, which may affect normal digestion and metabolism of nutrients in animals [66]. In moringa, tannins and phytates are 12 and $21 \mathrm{~g} \mathrm{~kg}^{-1}$ of DM, respectively, which can be neutralized by different feed processing techniques, including chopping, socking, heat steaming, and fermentation with beneficial organisms [65]. Considering the health benefit effects of moringa, it is a unique plant due to its enriching minerals with lower anti-nutritional components [65].

\section{Application of M. oleifera on Performance in Chickens}

In most of the feeding experiments in poultry, the fresh, green, and undamaged mature M. oleifera leaves were properly air-dried, and then the dried leaves were ground to a fine powder in a hammer mill and considered as moringa leaf powder or leaf meal. Similarly, fresh mature moringa seeds were air-dried and ground and considered as moringa seed meal. In some experiments, the ground particles were then soaked into distilled water for $24 \mathrm{~h}$, and the filtered aqueous solution was considered as moringa extract. Due to the rich nutrient content, especially the high amount of crude protein $(\mathrm{CP})$, vitamins, and minerals, $M$. oleifera leaves can be used as a useful resource of dietary supplementation for livestock as well as poultry [65-67]. In addition, Briones et al. [68] stated that moringa leaves can be applied as a dietary supplement in layers and broilers due to high production performance and improved eggs quality. However, still there are many debates on the chicken's performance with different doses of $M$. oleifera in the previous studies. There are also many variables on doses and part of plant used, such as leaves, extract, sods, or seeds. Finally, many scientists agreed that M. oleifera plant might have a positive role in improving the production performance and health status in chickens. Further studies are still needed to detect the actual doses of application for optimum performance in chickens.

\subsection{Effects of M. oleifera on Growth Performance in Broilers}

The major findings on the role of Moringa oleifera on performance in broilers are summarized in Table 3. Alabi et al. [69] applied aqueous M. oleifera leaf extracts on the performance in broiler chickens. This study demonstrates that average daily body weight gain and final body weight were higher in $120 \mathrm{~mL} / \mathrm{L}$ extract-supplemented groups than the control. Feed intake was highest in birds on positive control (having antibiotics) and lowest in birds that consumed $90 \mathrm{~mL} /$ liter of leaf extracts. 
Feed conversion ratio (FCR) was lower in birds on $90 \mathrm{~mL} / \mathrm{L}$ and $120 \mathrm{~mL} / \mathrm{L}$ of leaf extracts fed groups. Collectively, the authors suggested that moringa leaf extracts can be added up to $90 \mathrm{~mL} / \mathrm{L}$ in broiler chickens for optimum performance. The higher body weight and lower FCR in this study might be related to the presence of different bioactive components in moringa leaf extracts that may play a role in improved nutrient utilization in supplemented birds. Similarly, higher body weight was also recorded by Khan et al. [70] who used moringa leaf powder as dietary supplement with $1.2 \%$ levels in broilers. Abdulsalam et al. [71] conducted an experiment with moringa leaf meal in broilers and found that supplemented diets could enhance the growth performance at finisher period. The authors finally stated that moringa leaf meal can be applied as a natural source of protein in broiler diets. Similarly, inclusion of Moringa oleifera leaves at higher levels (15\% and $20 \%$ ) in broiler diets resulted in a higher growth rate and better health status in broilers [14]. In addition, dietary supplementation of M. oleifera leaves at $5 \%$ to $20 \%$ level showed higher growth performance in broilers [66]. Final live weight, average weight gain, and FCR were higher in $10 \%$ moringa leaf meal supplemented diets than the control through a 35-day trial period [72].Furthermore, feeding with M. oleifera leaf powder could improve live weight, body weight gain, dressing percentage, and FCR in broilers [73].

In contrast, no significant differences were observed on growth performance and economic parameters in broilers fed with Moringa oleifera leaf meal, according to Onunkwo and George [18]. Finally, the authors stated that Moringa oleifera leaf meal may be used at the level of $10 \%$ with view to reducing the production cost [18]. Similarly, feeding with moringa leaf meal in broilers led to a lower feed intake with higher FCR, as reported by Gakuyaet al. [74], which was due to presence of anti-nutritional factors in moringa leaves used in the experiment diets as row basis. No significant differences were observed on final live weight and dressing percentage by feeding moringa seed powder in broilers [75]. Gadzirayi et al. [76] applied Moringa oleifera leaf meal as supplementing part of conventional soybean meal in broiler diets at $0 \%, 25 \%, 50 \%, 75 \%$, and $100 \%$ level. The author did not find any significant differences on feed intake and body weight gain between control and $25 \%$ level of moringa supplementation. However, significantly lower FCR was observed in moringa leaf meal fed groups. Finally, the study suggested using moringa leaf meal at a $25 \%$ level to promote growth in broilers. In addition, Ayssiwede et al. [77] noted that dietary application of moringa leaf meal up to a level of $24 \%$ had no adverse effects on body weight, average daily weight gain, FCR, mortality, and the weight of organs in broilers compared to the control diet. Olugbemi et al. [78] stated that average daily growth rate was lower with Moringa oleifera leaf meal at the inclusion level below $5 \%$ in diets, and the authors suggested to use maximum level of $5 \%$ without any harmful effects on growth performance and FCR in broilers. These findings confirmed the fact that feeding with moringa leaves had no deleterious effects on normal physiology and growth in the experimental broilers. However, collectively, some authors suggested that use of the Moringa oleifera leaf meal up to a $10 \%$ level would not have any adverse effects in broilers [78-80] 
Table 3. Role of Moringa oleifera on performance in broilers. ${ }^{\dagger}$

\begin{tabular}{|c|c|c|c|}
\hline Types & Study Design & Main Findings & References \\
\hline Moringa oleifera leaf powder & $\begin{array}{c}\text { broilers (Hubbard) from } 1-35 \text { days, } \\
\text { dose: } 6,9,12 \text {, and } 15 \mathrm{~g} / \mathrm{kg} \text { (supplementation type) }\end{array}$ & $\begin{array}{l}\text { ๑higher } \mathrm{pH} \text { of breast muscle } \\
\text { ๑higher weight and diameter of breast muscle fibers } \\
\text { ๑higher water holding capacity of breast muscle } \\
\text { @higher weight length index of tibia bone } \\
\text { @higher ash percentage of tibia bone } \\
\text { @no effects on alkaline phosphatase in tibia bone }\end{array}$ & [81] \\
\hline Moringa oleifera leaf powder & $\begin{array}{l}\text { broilers (Hubbard) from } 1-35 \text { days, } \\
\text { dose: } 0,0.6 \%, 0.9 \%, 0.12 \%, 0.15 \% \\
\quad \text { (supplementation type) }\end{array}$ & $\begin{array}{l}\text { ๑no effects on feed intake, FCR and bursa weight } \\
\text { ๑higher final body weight } \\
\text { ๑higher length of small intestine } \\
\text { ๑higher empty weight of small intestine and ceca } \\
\text { ๑higher villus height (duodenum, jejunum, ileum) } \\
\text { ๑higher villus height/crypt depth (ileum) } \\
\text { ๑higher goblet cell number (total) in duodenum } \\
\text { ๑higher acidic mucin number in duodenum, jejunum and ileum } \\
\text { @higher body weight gain }\end{array}$ & [70] \\
\hline Moringa oleifera leaf extract & $\begin{array}{l}\text { broilers (Hubbard)from } 1-42 \text { days, } \\
\text { dose: } 0,60,90,120,150 \mathrm{~mL} / \mathrm{L}\end{array}$ & $\begin{array}{l}\text { ๑lower FCR } \\
\text { ๑no effects on weight of inner organs } \\
\text { ๑no effects on dressing percentage }\end{array}$ & [69] \\
\hline Moringa oleifera leaf meal & $\begin{array}{c}\text { broilers from } 0-42 \text { days, } \\
\text { dose: } 0,5 \%, 10 \% 15 \%, 20 \% \text {, (inclusion type) }\end{array}$ & $\begin{array}{l}\text { ๑higher body weight } \\
\text { ๑higher hemoglobin percent, and RBC number } \\
\text { •lower TC, LDL }\end{array}$ & [14] \\
\hline Moringa oleifera seed powder & $\begin{array}{c}\text { broilers from } 1-42 \text { days, } \\
\text { dose: } 0,0.5 \%, 0.1 \% \text {, and } 2 \% \text { (inclusion type) }\end{array}$ & $\begin{array}{l}\text { ๑no effects on live weight and weight gain } \\
\text { @no effects on FCR } \\
\text { ๑no effects on dressing percentage, liver weight and heart weight }\end{array}$ & [75] \\
\hline Moringa oleifera leaf meal & $\begin{array}{l}\text { broilers (ANIK } 2000 \text { strain) from } 0-49 \text { days, } \\
\text { dose: } 0,5 \%, 7.5 \%, 10 \% \text { (inclusion type) }\end{array}$ & $\begin{array}{l}\text { ๑higher dressing weight in } 7.5 \% \text { and } 10 \% \text { level } \\
\text { ๑higher weight of liver, spleen, and gizzard } \\
\text { ๑no significant effects on body weight gain, feed intake and FCR } \\
\text { ๑higher body weight and weight gain at grower period }\end{array}$ & [18] \\
\hline Moringa oleifera leaf meal & $\begin{array}{c}\text { broilers (Cobb-500) from } 1-35 \text { days, } \\
\text { dose: starter (1, } 3 \text { and } 5 \mathrm{~g} / \mathrm{kg}) \text {; grower }(3,9 \text {, and } \\
15 \mathrm{~g} / \mathrm{kg}) ; \text { and finisher }(5,15 \text {, and } 25 \mathrm{~g} / \mathrm{kg}) \\
\text { (inclusion type) }\end{array}$ & $\begin{array}{l}\text { ๑lower FCR } \\
\text { ๑no effects on feed intake } \\
\text { ๑higher Ca and P content in tibia bone } \\
\text { ๑no effects on tibia weight, tibia length, and weight-length index of tibia bone } \\
\text { @no effects on ash content in tibia, and bone breaking strength }\end{array}$ & [82] \\
\hline Moringa oleifera leaf meal & $\begin{array}{c}\text { broilers (Cobb-500) from } 1-35 \text { days, } \\
\text { dose: starter }(1,3 \text {, and } 5 \mathrm{~g} / \mathrm{kg}) \text {, grower }(3,9 \text {, and } \\
15 \mathrm{~g} / \mathrm{kg}) \text { and finisher }(5,15 \text {, and } 25 \mathrm{~g} / \mathrm{kg}) \\
\text { (inclusion type) }\end{array}$ & $\begin{array}{c}\text { ๑higher body weight at starter and finisher period } \\
\text { @lower FCR } \\
\text { @no effects on feed intake } \\
\text { •higher dressing percentage, thigh muscle weight and bursa weight } \\
\text { ๑no effects on CP, CF, DM, EE, ash, NDF, ADF digestibility }\end{array}$ & [83] \\
\hline
\end{tabular}


Table 3. Cont

\begin{tabular}{|c|c|c|c|}
\hline Types & Study Design & Main Findings & References \\
\hline Moringa oleifera leaf meal & $\begin{array}{l}\text { broilers (Cobb-500) from } 1-35 \text { days, } \\
\text { dose: } 1 \%, 3 \% \text {, and } 5 \% \text { (inclusion type) }\end{array}$ & 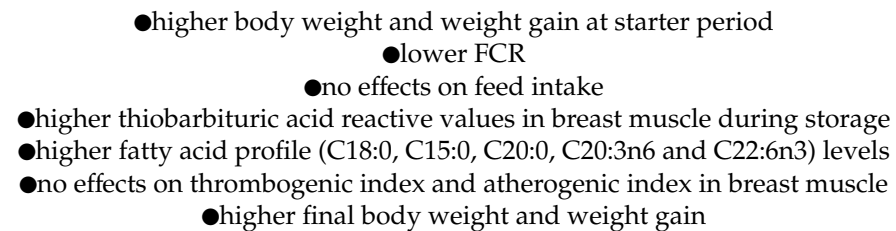 & [84] \\
\hline Moringa oleifera leaf meal & $\begin{array}{c}\text { broilers (Ross) from } 1-49 \text { days, } \\
\text { dose: } 0,3 \%, 5 \% \text {, and } 7 \% \text { (inclusion type) }\end{array}$ & $\begin{array}{c}\text { ๑lower FCR } \\
\text { ๑higher feed intake } \\
\text { ๑higher dressing percentage } \\
\text { ๑higher meat tenderness and juiciness score }\end{array}$ & [85] \\
\hline Moringa oleifera leaf meal & $\begin{array}{c}\text { broilers from } 1-42 \text { days, } \\
\text { dose: } 0,7.5 \%, 15 \% \text {, and } 30 \% \text { (inclusion type) }\end{array}$ & $\begin{array}{l}\text { @lower final body weight and weight gain } \\
\text { •higher FCR } \\
\text { @lower dry matter digestibility } \\
\text { ๑no effects on crude protein, crude fiber digestibility } \\
\text { ๑no effects on lipid metabolic profile (HDL, TC, LDL) } \\
\text { ๑higher meat color scores }\end{array}$ & {$[74]$} \\
\hline Moringa oleifera leaf meal & $\begin{array}{c}\text { broilers from } 1-35 \text { days, } \\
\text { dose: } 0,10 \%, 15 \% \text { (inclusion type) }\end{array}$ & $\begin{array}{l}\text { @higher body weight gain } \\
\text { @lower FCR } \\
\text { ๑higher final body weight } \\
\text { •higher RBC number, PCV number, and HB percent }\end{array}$ & [72] \\
\hline Moringa oleifera leaf meal & $\begin{array}{c}\text { broilers (Habbard) from } 0-42 \text { days, } \\
\text { dose: } 0,25 \%, 50 \%, 75 \%, 100 \% \text { (supplementation } \\
\text { type) }\end{array}$ & 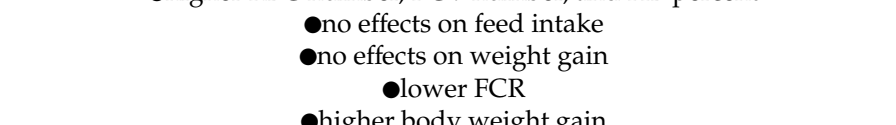 & [76] \\
\hline Moringa oleifera leaf powder & $\begin{array}{c}\text { broilers from } 1-42 \text { days, } \\
\text { dose: } 0,0.05 \%, 0.10 \% \text { (supplementation type) }\end{array}$ & $\begin{array}{l}\text { ๑higher body weight gain } \\
\text { @lower FCR } \\
\text { @higher final body weight } \\
\text { •higher dressing percentage } \\
\text { @higher live weight }\end{array}$ & [73] \\
\hline Moringa oleifera leaf extract & $\begin{array}{l}\text { broilers (Cobb)from } 1-35 \text { days, } \\
\text { dose: } 0,30,60,90 \mathrm{~mL} / \mathrm{L}\end{array}$ & $\begin{array}{c}\text { @lower FCR } \\
\text { •higher returns to investment } \\
\text { •lower feed intake }\end{array}$ & [86] \\
\hline Moringa oleifera leaf meal & $\begin{array}{c}\text { broilers (Cobb) from } 14-42 \text { days, } \\
\text { dose: } 0,5 \%, 10 \% \text {, and } 15 \% \text { (inclusion type) }\end{array}$ & $\begin{array}{l}\text { @ower weight gain and final body weight } \\
\text { @higher FCR } \\
\text { ๑no effects on dressing percentage and carcass weight } \\
\text { @no effects on weight of inner organs } \\
\text { ๑no effects on CP and EE content in meat } \\
\text { @no effects on total cholesterol, HDL, LDL, total protein, glucose }\end{array}$ & [87] \\
\hline
\end{tabular}

hemoglobin; $\mathrm{CP}$, crude protein; $\mathrm{CF}$, crude fiber; $\mathrm{DM}$, dry matter; $\mathrm{EE}$, ether extract; $\mathrm{NDF}$, neutral detergent fiber; $\mathrm{ADF}$, acid detergent fiber. 


\subsection{Effects of M. oleifera on Meat and Bone Quality in Broilers}

Dietary manipulation is an important way to improve the meat quality in poultry [2]. The meat derived from broiler chickens is an excellent source of protein, vitamins, minerals, and lower fat and has created a great demand among consumers [88]. Meat $\mathrm{pH}$, tenderness, color (lightness, redness, and yellowness), and water holding capacity are very important meat quality characteristics to the consumers. An experiment on supplementation of Moringa oleifera leaf powder on the quality of meat and bone in broilers was conducted by Rehman et al. [81]. This study noticed that supplementation of leaf powder at $12 \mathrm{~g} / \mathrm{kg}$ level could increase $\mathrm{pH}$, water holding capacity, and muscle fiber diameter in the breast muscle of experimental broilers. In addition, higher weight, ash percentage, and the density of tibia bone in broilers fed with moringa leaf meal were also recorded in their studies [81]. In this study, authors hypothesized that higher muscle $\mathrm{pH}$ values in experimental groups were due to the stabilization of the myofibrils by activating antioxidant properties and preventing free radicals. Higher breast muscle weight could be the result of increased protein deposition in moringa-supplemented groups. The higher tibia bone weight and ash percent may be due to the presence of phytoestrogen flavonoids in moringa leaves powder. In contrast, Nkukwana et al. [82] found that Moringa oleifera leaf meal had no effects on tibia bone characteristics but could improve body weight gain and FCR. These differences might be related with inclusion levels and types of incorporation of moringa in broiler diets. However, it is a popular belief that dietary antioxidants can modify the meat color, minimize the rancidity, and retard lipid peroxidation, resulting in a well-maintained meat quality. The oxidative status of meat muscle is directly related to meat quality and has negative effects on cooking loss, drip loss, meat color, and $\mathrm{pH}$ [89]. Therefore, dietary supplementation of antioxidant-enriched moringa leaves would be a potential strategy to improve the meat quality in broilers. Moreover, it was reported that phytosterols could reduce malondialdehyde (MDA) content and increase glutathione (GSH) concentration in the breast muscle of experimental broiler chickens [88]. The inclusion of moringa leaf meal could improve fatty acid profile and could reduce lipid oxidation in breast muscle of broilers [84]. The authors assumed that improved fatty acid profile was due to the presences of saturated fatty acids in moringa leaves.

\subsection{Effects of M. oleifera on Health Status in Broilers}

Alnidawi et al. [14] has conducted an experiment with a view to examining the effects of Moringa oleifera leaf on health status in broilers.This study ensured that total cholesterol content was lower with higher level (at 15\% and 20\%) of M. oleifera fed in broiler diets. Similarly, high-density lipoprotein cholesterol (HDL) content in serum was increased and low-density lipoprotein cholesterol (LDL) was decreased with higher level of supplementation of M. oleifera in broilers. It was hypothesized that higher amounts of natural fiber in moringa leaves may have a role in lowering cholesterol level by increasing lipid metabolism in the host body. In addition, the blood parameters, like hemoglobin percent, total red blood cells number, and total packed cell volume, were found to be higher at $20 \%$ supplementation levels than the control diet [14]. M. oleifera leaf powder was considered as dietary supplement with $0.6 \%, 0.9 \%, 1.2 \%$ and $1.5 \%$ levels in broilers on growth performance and intestinal microarchitecture [70]. The intestine's morphological characteristics in chickens are vital for nutrient utilization and an indicator of sound physiology. The length and empty weight of small intestine were found higher in broilers fed with $1.2 \%$ leaves powder. In addition, higher villus height (duodenum, jejunum, ileum), villus surface area (duodenum), and villus height/crypt depth (ileum) were observed in $1.2 \%$ leaves powder fed group than the control. Higher villi suggest better absorption of nutrients due to enlarged surface area, which is a good indicator of gut system. Furthermore, the improvement of villus height and villus height/crypt depth ratio may be linked with high content of crude fiber in moringa-supplemented diets. This study further observed that total goblet cells of duodenum were higher in broilers fed with all levels of $M$. oleifera leaf powder in comparison with control group. The findings indicate enhanced mucosal protection with $M$. oleifera supplementation in broiler diets. Goblet cells are essential elements of innate gut immune system in poultry. Bursal follicle count was 
also found to be higher in $1.2 \%$ M. oleifera-fed group than non-supplemented control diet. Finally, the authors concluded that dietary supplementation of $M$. oleifera at $1.2 \%$ level could modulate the intestinal structure and acidic mucin production without any adverse effects on growth performance in broilers [70].

The extract from the leaves of Moringa oleifera has apotential role as an anti-bacterial and antioxidant functions [22]. The roles of Moringa oleifera leaf meal at $10 \%$ and $15 \%$ level on the hematological parameters in broilers were examined by Ebenebe et al. [72]. Feeding Moringa leaf meal in broilers resulted in increased red blood cell (RBC), packed cell volume (PCV), and hemoglobin (HB) values in both levels of diets. Finally, the authors stated that Moringa oleifera leaf meal should be used within the $10 \%$ level in broiler diets. Moringa oleifera is known to a potential antioxidant with some antioxidant properties due to the presence of vitamins C and E, carotenoids, flavonoids, and selenium [15]. Moringa oleifera leaves contain various phytochemicals (carotenoids, flavonoids, chlorophyll, phenolics, xanthins, cytokines, alkaloids, etc.) that might have a role in improving health status [90].

\subsection{Effects of M. oleifera on Egg Production, Performance, and Egg Quality in Laying Hens}

The major findings on the role of M. oleifera in performance in laying hens are summarized in Table 4. The egg quality parameters, including egg size, shape, color, shell thickness, and egg yolk cholesterol, directly and indirectly influence egg consumers. In a recent study by Voemesse et al. [91], M. oleifera leaf meal was used in layer chickens' diet from 1 day old to 55 weeks of age to investigate the effects of moringa leaf meal on growth performance, egg production performance, and blood parameters. M. oleifera leaf meal was used at three different levels $(0 \%, 1 \%$, and $3 \%)$. In the growing period from 1 day to 20 weeks of age, this study did not find any significant differences on feed intake, but average daily body weight gain, final body weight, and FCR were improved in M. oleifera-supplemented groups. In the laying period, from 21 weeks to 55 weeks, feed intake was lower in moringafed groups, but the laying percent and FCR were higher in supplemented fed groups than the non-supplemented group. The higher body weight gain and egg production may be related to improved digestibility in supplemented groups due to different active components in moringa leaves. The author concluded that feeding moringa leaf meal at $1 \%$ level had positive effects on the growth and egg production in laying hens.In addition, Moring oleifera at 10\% levels showed higher egg production in laying hens [66]. According to Abouz-Elezz et al. [92], M. oleifera supplementation could improve the egg production, egg mass, and egg yolk color scores compared with the non-supplemented groups. The improvement of yolk color scores could be due to high carotene content in moringa leaves. Higher feed intake, crude protein intake, weight gain, FCR, and protein efficiency ratios were recorded in laying chicks where Moringa stenopetala was the experimental supplement [93]. This is because of readily available proteins with their essential amino acids in the moringa leaf meal. The authors finally concluded that Moringa stenopetala leaf meal at up to $6 \%$ levels can be applied in growing chicks' ration.

In contrast, Moringa oleifera seed meal at $0 \%, 1 \%, 3 \%$ and $5 \%$ levels were used to examine the effects of egg production performance, egg quality, and egg fatty acid profile in Hy-Line laying hens [94]. Lower feed intake, egg production percent, egg mass, feed intake, and body weight were observed in moringa seed meal-fed groups than the control. Higher egg yolk color scores with higher linolelaidic acid in egg yolk were found in moringa seed meal supplemented groups than the non-supplemented diets [94]. The moringa seeds may contain different anti-nutritional factors, which may have deleterious effects on production performance in this study. In addition, Ahmad et al. [95] also reported that the decrease in production performance of layer chickens was due to high fiber and different anti-nutritional factors' presences in moringa pod meal. However, this study found a significant positive role in improving $\beta$-carotene, quercetin, and selenium levels in egg yolk with moringa pod supplementation. Moringa pods are naturally enriched with carotenoids and different flavonoids, which possess natural antioxidants that could modify the $\beta$-carotene and quercetin levels in egg yolk [74]. Egg yolk cholesterol was significantly lower in moringa pod meal fed groups than the control group, which may be due to presence of natural antioxidants in the experimental diets 
containing moringa pod meal in this study. In addition, the nutrient profile of egg yolk was higher with the supplementation of moringa pod meal in Hy-Line layers [95]. In another study, Lu et al. [96] found that $M$. oleifera leaf meal had no effects on egg production, egg weight, and feed intake in Hy-Line Grey commercial layers, but birds fed with moringa leaf meal at $15 \%$ levels showed deeper egg yolk color than the non-supplemented fed group. Similarly, the albumen height and Haugh unit were higher in moringa-supplemented groups during storage of eggs at $4{ }^{\circ} \mathrm{C}$ and $28^{\circ} \mathrm{C}$ for 4 weeks. Finally, the author stated that $5 \%$ moringa leaves meal can be included in laying hens' ration without adverse effects on egg production and egg quality. Similarly, Abou-Elezz et al. [80] found that Moringa oleifera leaf meal could improve egg yolk color scores and albumen percentage. This study further observed the lower egg laying percentage and egg mass in laying hens fed with moringa leaf meal. However, this study did not find any significant differences on final body weight and on other egg quality parameters (yolk percent, shell percent, and shell thickness). Finally, the author stated that $10 \%$ moringa leaf meal can be incorporated into the diets of Rhode Island Red laying hens. Feed intake, feed conversion ratio, and laying percentage were not influenced by adding moringa leaf meal at a $10 \%$ level, which was noticed by Olugbemi et al. [78]. However, inclusion of $10 \%$ moringa leaf meal could increase higher egg Roche color score [78]. A similar report on decreased egg mass and egg production percent with moringa leaf meal supplementation at higher levels (at $10 \%$ and $20 \%$ ) in laying hens was observed by Kakengi et al. [79]. Interestingly, Moringa oleifera leaf meal at $5 \%$ level increased the egg weight, but the decreased egg weight was found when inclusion level was at $20 \%$. The authors assumed that higher feed intake, FCR with lower egg production percent, egg mass, and egg weight at a higher-level supplementation was due to poor digestibility of nutrients because of different anti-nutritional phytochemical presences in moringa leaves [79].

Improving the egg quality by means of increasing its anti-oxidative properties by supplementing natural unconventional resources has gained a significant interest in poultry research [97]. The synthesis antioxidants, like butylated hydroxyanisole and butylated hydroxytoluene, are commonly used in food processing. However, they are found to be carcinogenic to human health, therefore, discovering natural antioxidant products as safe and effective alternatives is a very crucial need [98-100]. 
Table 4. Role of Moringa oleifera on performance in laying hens. ${ }^{+}$

\begin{tabular}{|c|c|c|c|}
\hline Types & Study Design & Main Finding & References \\
\hline Moringa oleifera leaf meal & $\begin{array}{l}\text { laying chickens and laying hens, } \\
\text { from } 1 \text { day to } 55 \text { weeks, } \\
\text { dose: } 0,1 \%, 2 \% \text {, and } 3 \% \text { (inclusion type) }\end{array}$ & 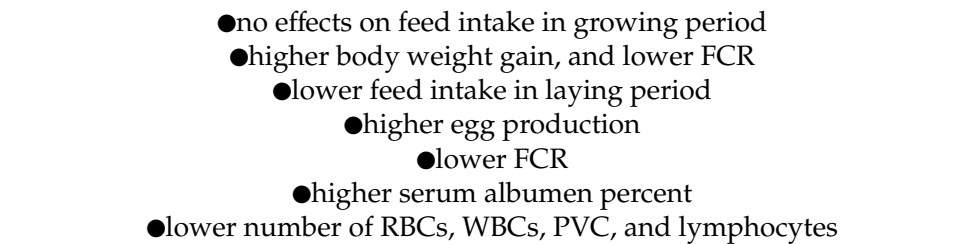 & [91] \\
\hline Moringa oleifera seed meal & $\begin{array}{c}\text { laying chickens (Hy-Line), } \\
\text { from } 20-28 \text { weeks, } \\
\text { dose: } 0,1 \%, 3 \% \text {, and } 5 \% \text { (inclusion type) }\end{array}$ & $\begin{array}{c}\text { ๑lower egg production percent, egg mass, feed intake and body weight } \\
\text { ono effects on egg weight } \\
\text { @lower egg albumen height } \\
\text { @higher egg yolk color scores } \\
\text { ๑no effects on albumen weight, yolk weight, egg shell weight, and egg shape } \\
\text { index } \\
\text { @lower palmitoleic acid in egg yolk } \\
\text { •higher linolelaidic acid in egg yolk } \\
\text { @higher egg mass and lower FCR }\end{array}$ & [94] \\
\hline Moringa oleifera pod meal & $\begin{array}{c}\text { laying hens (Hy-Line), } \\
\text { from } 50-66 \text { weeks, } \\
\text { dose: } 0,5,10 \text { and } 15 \mathrm{~g} / \mathrm{kg} \text { (inclusion type) }\end{array}$ & $\begin{array}{l}\text { ๑no effects on egg production, egg weight, and feed intake } \\
\text { ๑higher Haugh unit and egg shell thickness } \\
\text { ono effects on egg shape index and egg yolk index } \\
\text { ๑higher } \beta \text {-carotene, quercetin, and selenium in egg yolk } \\
\text { •lower cholesterol in egg yolk and serum } \\
\text { ๑higher nutrient composition in egg yolk }\end{array}$ & [95] \\
\hline Moringa oleifera leaf meal & $\begin{array}{l}\text { laying hens (Hy-line Gray) from } 27-35 \text { weeks, } \\
\text { dose: } 0,5 \%, 10 \% \text {, and } 15 \% \text { (inclusion type) }\end{array}$ & $\begin{array}{c}\text { ๑no effects on feed intake and egg weight } \\
\text { @higher FCR } \\
\text { @lower egg production } \\
\text { @higher egg yolk color scores } \\
\text { ๑higher albumen height and Haugh unit during storage } \\
\text { @higher glutathione peroxidase in plasma } \\
\text { ๑lower malondialdehyde and uric acid in plasma }\end{array}$ & [96] \\
\hline Moringa oleifera leaf powder & $\begin{array}{c}\text { laying hens (Lohmann LSL) } \\
\text { from } 27-40 \text { weeks, } \\
\text { dose: } 0,0.2 \%, 0.4 \%, 0.6 \%, 0.8 \% \text { (inclusion type) }\end{array}$ & $\begin{array}{l}\text { ๑no effects on egg production, egg weight, and FCR } \\
\text { ๑no effects on sensory evaluation of eggs quality } \\
\text { ๑no effects on egg shell thickness } \\
\text { @higher egg production }\end{array}$ & [101] \\
\hline Moringa oleifera leaf meal & $\begin{array}{l}\text { laying hens (Rhode Island Red, RIR) } \\
\text { from 27-38 weeks, } \\
\text { dose: } 0,300 \mathrm{~g} / \mathrm{kg} \text {, (supplementation type) }\end{array}$ & $\begin{array}{l}\text { ๑higher egg mass } \\
\text { •higher egg yolk color scores } \\
\text { •lower FCR } \\
\text { •higher albumen percent }\end{array}$ & [92] \\
\hline
\end{tabular}


Table 4. Cont.

\begin{tabular}{|c|c|c|c|}
\hline Types & Study Design & Main Finding & References \\
\hline Moringa oleifera leaf meal & $\begin{array}{c}\text { laying hens (Rhode Island Red, RIR) } \\
\text { from } 36-41 \text { weeks, } \\
\text { dose: } 0,5 \%, 10 \% \text {, and } 15 \% \text { (inclusion type) }\end{array}$ & $\begin{array}{l}\text { ๑no effects on final body weight, egg weight, and FCR } \\
\text { @ecreased egg production } \\
\text { @decreased egg mass } \\
\text { •higher egg yolk color scores } \\
\text { @higher albumen percent } \\
\text { @no effects on yolk percent, shell percent, and shell thickness }\end{array}$ & [80] \\
\hline Moringa oleifera leaf meal & $\begin{array}{c}\text { laying hens } \\
\text { from } 65-73 \text { weeks, } \\
\text { dose: } 0,5 \%, 10 \% \text {, and } 20 \% \text { (inclusion type) }\end{array}$ & $\begin{array}{l}\text { @no effects on feed intake, egg production percent, and FCR } \\
\text { @decreased feed cost } \\
\text { @no effects on albumen and yolk percent } \\
\text { @higher egg Roche color scores }\end{array}$ & [78] \\
\hline
\end{tabular}

${ }^{\dagger}$ FCR, feed conversion ratio; RBC, red blood cell; WBC, white blood cell; PCV, packed cell volume. 


\subsection{Effects of M. oleifera on Health Status in Laying Hens}

Analyzing blood parameters is very important in detecting the health status of birds. According to Voemesse et al. [91], serum albumin level was higher in laying hens fed with $3 \%$ level of moringa leaf meal than the control group, but the number of white blood cells (WBCs),red blood cells (RBCs), lymphocytes, and the packed cell volume were lower in moringa-fed groups than the control diets. The authors assumed that lower WBCs and lymphocytes in moringa-fed chickens may be due to the antimicrobial activity of phytochemicals in the moringa leaves. It is well known that a high WBC count is related to an infection caused by bacteria in the host. Lower level of cholesterol content in serum with dietary supplementation of moringa pod meal were observed, which might be influenced by antioxidants (flavonoids and carotenoids) and high fiber presences in the moringa pod meal in the experimental diets [95]. However, this study did not find any significant differences on antibody response against Newcastle disease virus. Lower values for malondialdehyde (MDA) and higher glutathione peroxidase in the plasma of laying hens fed with moringa leaf meal indicated the higher antioxidant activities [96]. Plasma total protein levels were higher by dietary $5 \%$ for moringa leaf meal supplementation, which is a good indicator of the liver's synthetic function. Furthermore, lower plasma uric acid in supplemented groups indicated higher protein retention in laying hens [96]. The improved antioxidant enzyme activities and the reduced MDA levels in the plasma and egg yolk indicated the fact that dietary moringa supplementation could improve the antioxidant activities. Moringa oleifera is an effective phytobiotic and is known to possess broad-spectrum antibacterial properties and immuno-modulatory functions $[70,81,102]$.

\section{Conclusions}

This review study highlights that $M$. oleifera could be fruitfully used as an effective natural growth promoter as well as an immune-boosting agent in chickens' ration. Although M. oleifera was used in the experimental diets of poultry, further study was recommended by various researchers regarding the doses of M. oleifera on optimum performance and sound health in chickens. Thus, the future study should beconducted ina proper way so that it will examine the uses of $M$. oleifera in reaction to a pathogen challenge as well as dosages. In this study, we suggest future research with M. oleifera as an alternative for antibiotics in chickens so that it may be used as an effective strategy for organic meat and egg production. It could be concluded that $M$. oleifera can be used as an environmentally friendly feed supplement in chicken ration. The present study will help future researchers to discover the important effects of M. oleifera on immunity and health status that the past studies were not able to explore. Thus, the supplementation with M. oleifera may be a new concept of research in chicken production. The inclusion level of $M$. oleifera up to $10 \%$ in both broilers' and laying hens' diet could be recommended.

Author Contributions: Conceptualization, X.S.P.; Preparation of Manuscript, S.M., and Scientific Editing, X.S.P. and S.M.

Funding: This research received no external funding.

Acknowledgments: The author would like to express their sincere gratitude to the College of Animal Science and Technology, China Agricultural University (CAU) for financially support from the National Natural Science Foundation of China (31772612) for his post-doctoral study under Xiang Shu Piao.

Conflicts of Interest: There is no conflict of interest relevant to this publication.

\section{References}

1. Anwar, M.I.; Muhammad, F.; Awais, M.M.; Akhtar, M. A review of $\beta$-glucans as a growth promoter and antibiotic alternative against enteric pathogens in poultry. World's Poult. Sci. J. 2017, 73, 651-661. [CrossRef]

2. Cheng, Y.; Chen, Y.; Li, J.; Qu, H.; Zhao, Y.; Wen, C.; Zhou, Y. Dietary $\beta$-Sitosterol improves growth performance, meat quality, antioxidant status, and mitochondrial biogenesis of breast muscle in broilers. Animals 2019, 9, 71. [CrossRef] [PubMed] 
3. Movahhedkhah, S.; Rasouli, B.; Seidavi, A.; Mazzei, D.; Laudadio, V.; Tufarelli, V. Summer savory (Satureja hortensis L.) extract as natural feed additive in broilers: Effects on growth, plasma constituents, immune response, and ileal microflora. Animals 2019, 9, 87. [CrossRef] [PubMed]

4. Mahanta, J.D.; Borgohain, B.; Sarma, M.; Sapcota, D.; Hussain, J. Effect of dietary supplementation of herbal growth promoter on performance of commercial broiler chicken. Indian J. Anim. Resh. 2017, 51, 1097-1100.

5. Mahfuz, S.; Song, H.; Wei, J.; Chen, M.; Zhen, D.; Nahar, Z.; Liu, Z. Organic egg production, egg quality, calcium utilization, and digestibility in laying hens fed with mushroom (Flammulina velutipes) stem waste. Brazilian J. Poult. Sci. 2018, 20, 717-724. [CrossRef]

6. Mahfuz, S.U.; Chen, M.; Zhou, J.S.; Wang, S.; Wei, J.; Liu, Z.; Song, H. Evaluation of golden needle mushroom (Flammulina velutipes) stem waste on pullet performance and immune response. South African J. Anim. Sci. 2018, 48, 563-571. [CrossRef]

7. Pourhossein, Z.; Qotbi, A.A.A.; Seidavi, A.; Laudadio, V.; Centoducati, G.; Tufarelli, V. Effect of different levels of dietary sweet orange (Citrus sinensis) peel extract on humoral immune system responses in broiler chickens. Anim. Sci. J. 2015, 86, 105-110. [CrossRef] [PubMed]

8. Mahfuz, S.; Song, H.; Miao, Y.; Liu, Z. Dietary inclusion of mushroom (Flammulina velutipes) stem waste on growth performance and immune responses in growing layer hens. J. Sci. Food Agric. 2018, 99, 703-710. [CrossRef]

9. Arora, D.S.; Onsare, J.G.; Kaur, H. Bioprospecting of Moringa (Moringaceae): microbiological perspective. J. Pharmacogn. Phytochem. 2013, 1, 193-215.

10. Gopalakrishnan, L.; Doriya, K.; Kumar, D.S. Moringa oleifera: A review on nutritive importance and its medicinal application. Food Sci. Human Wellness 2016, 5, 49-56. [CrossRef]

11. Gupta, S.; Jain, R.; Kachhwaha, S.; Kothari, S.L. Nutritional and medicinal applications of Moringa oleifera Lam-Review of current status and future possibilities. J. Herbal Med. 2018, 11, 1-11. [CrossRef]

12. Fahey, J.W. Moringa oleifera: a review of the medical evidence for its nutritional, therapeutic, and prophylactic properties. Part 1. Trees Life J. 2005, 1, 1-15.

13. Anwar, F.; Sajid, L.; Muhammad, A.; Anwarul, H.G. Moringa oleifera: A food plant with multiple medicinal uses. Phytother. Res. 2007, 21, 17-25. [CrossRef] [PubMed]

14. Alnidawi, A.; Ali, F.; Abdelgayed, S.; Ahmed, F.; Farid, M. Moringa oleifera leaves in broiler diets: Effect on chicken performance and health. Food Sci. Quality Manag. 2016, 58, 40-48.

15. Moyo, B.; Masika, P.J.; Muchenje, V. Potential use of Moringa oleifera leaf in animal feeding: A Rreview. Int. J. Current Agric. Res. 2016, 4, 9187-9194.

16. Oyeyinka, A.T.; Oyeyinka, S.A. Moringa oleifera as a food fortificant: Recent trends and prospects. J. Saudi Society Agric. Sci. 2018, 17, 127-136. [CrossRef]

17. Olugbemi, T.S.; Mutayoba, S.K.; Lekule, F.P. Effect of Moringa (Moringa oleifera) inclusion in cassava based diets fed to broiler chickens. Int. J. Poult. Sci. 2010, 9, 363-367. [CrossRef]

18. Onunkwo, D.N.; George, O.S. Effects of Moringa oleifera leaf meal on the growth performance and carcass characteristics of broiler birds. J. Agric. Vet. Sci. 2015, 8, 63-66.

19. Kalibbala, H.M.; Wahlberg, O.; Hawumba, T.J. The impact of Moringa oleifera as a coagulant aid on the removal of trihalomethane (THM) precursors and iron from drinking water. Water Sci.Technol: Water Supply 2009, 9, 707-714. [CrossRef]

20. Leone, A.; Spada, A.; Battezzati, A.; Schiraldi, A.; Aristil, J.; Bertoli, S. Cultivation, genetic, ethnopharmacology, phytochemistry and pharmacology of Moringa oleifera leaves: An overview. Int. J. Mol. Sci. 2015, 16, 12791-12835. [CrossRef]

21. Abbas, T.E. The use of Moringa oleifera in poultry diets. Turkish J. Vet Anim Sci. 2013, 37, 492-496. [CrossRef]

22. Sreelatha, S.; Padma, P.R. Antioxidant activity and total phenolic content of Moringa oleifera leaves in two stages of maturity. Plant Foods Human Nutri. 2009, 64, 303-311. [CrossRef] [PubMed]

23. Makkar, H.P.; Francis, G.; Becker, K. Bioactivity of phytochemicals in some lesser-known plants and their effects and potential applications in livestock and aquaculture production systems. Animal 2007, 1, 1371-1391. [CrossRef] [PubMed]

24. Mahajan, S.; Mali, R.; Mehta, A. Protective effect of ethanolic extract of seeds of Moringa oleifera Lam. against inflammation associated with development of arthritis in rats. J. Immunotoxicol. 2007, 4, 39-47. [CrossRef] [PubMed] 
25. Torondel, B.; Opare, D.; Brandberg, B.; Cobb, E.; Cairncross, S. Efficacy of Moringa oleifera leaf powder as a hand- washing product: A crossover controlled study among healthy volunteers. BMC Complementary Alternative Med. 2014, 14, 57. [CrossRef] [PubMed]

26. Anwar, F.; Rashid, U. Physicochemical characteristics of Moringa oleifera seeds and seed oil from a wild provenance of Pakistan. Pak. J. Botany 2007, 39, 1443-1453.

27. Ogbunugafor, H.A.; Eeneh, F.U.; Ozumba, A.N.; Igwo-ezikpe, M.N.; Okpuzor, J.; Igwilo, I.O.; Adenekan, S.O.; Onyekwelu, O.A. Physico-chemical and anti-oxidant properties of Moringa oleifera seed oil. Pak. J. Nutri. 2011, 10, 409-414.

28. Sofidiya, M.O.; Odukoya, O.A.; Familoni, O.B.; Inya-agha, S.I. Free-radical scavenging activity of some Nigerian medicinal plant extracts. Pak. J. Biologi. Sci. 2006, 9, 1438-1441.

29. Agbogidi, O.; Ilondu, E. Moringa oleifera Lam: its potentials as a food security and rural medicinal item. J. Bio. Innov. 2012, 1, 156-167.

30. Babayeju, A.; Gbadebo, C.; Obalowu, M.; Otunola, G.; Nmom, I.; Kayode, R.; Toye, A.; Ojo, F. Comparison of organoleptic properties of egusi and efo riro soup blends produced with moringa and spinach leaves. Food Sci. Qual. Manag. 2014, 28.

31. Chinma, C.E.; Abu, J.O.; Akoma, S.N. Effect of germinated tigernut and moringa flour blends on the quality of wheat-based bread. J. Food Processing Preserv. 2014, 38, 721-727. [CrossRef]

32. Kolawole, F.; Balogun, M.; Opaleke, D.; Amali, H. An evaluation of nutritional and sensory qualities of wheat-moringa cake. Agrosearch 2013, 13, 87-94. [CrossRef]

33. Hekmat, S.; Morgan, K.; Soltani, M.; Gough, R. Sensory evaluation of locally-grown fruit purees and inulin fibre on probiotic yogurt in Mwanza, Tanzania and the microbial analysis of probiotic yogurt fortified with Moringa oleifera. J. Health, Population Nutri. 2015, 33, 60-67.

34. Qwele, K.; Hugo, A.; Oyedemi, S.O.; Moyo, B.; Masika, P.J.; Muchenje, V. Chemical composition, fatty acid content and antioxidant potential of meat from goats supplemented with moringa (Moringa oleifera) leaves, sunflower cake and grass hay. Meat Sci. 2013, 93, 455-462. [CrossRef] [PubMed]

35. Saini, R.K.; Shetty, N.P.; Prakash, M.; Giridhar, P. Effect of dehydration methods on retention of carotenoids, tocopherols, ascorbic acid and antioxidant activity in Moringa oleifera leaves and preparation of a RTE product. J. Food Sci. Technol. 2014, 51, 2176-2182. [CrossRef]

36. Sharma, R.; Singh, V.J. In vivo antioxidant activity of Moringa oleifera leaf and pod extracts against carbon tetrachloride induced liver damage in albino mice. J. chem. Pharm. Res. 2010, 2, 275-283.

37. Jaiswal, D.; Kumar, P.R.; Chatterji, S.M.S.; Shukla, S.; Rai, D.K.; Sharma, G.; Sharma, B.; khair, S.; Watal, G. Role of Moringa oleifera in regulation of diabetes-induced oxidative stress. Asian Pacific J. Tropic. Med. 2013, 10, 426-432. [CrossRef]

38. Luqman, S.; Srivastava, S.; Kumar, R.; Maurya, A.K.; Chanda, D. Experimental assessment of Moringa oleifera leaf and fruit for its antistress, antioxidant and scavenging potential using in vitro and in vivo assays. Evi. Bas. Compl. Alt. Med. 2012, 519084, 12.

39. Khalafalla, M.M.; Abdellatef, E.; Dafalla, H.M.; Nassrallah, A.A.; Aboul-Enein, K.M.; Lightfoot, D.A.; El-Deeb, F.E.; El-Shemy, H.A. Active principle from Moringa oleifera Lam leaves effective against two leukemias and a hepatocarcinoma. Afr. J. Biotechnol. 2010, 9, 8467-8471.

40. Pamok, S.; Vinitketkumnuen, S.S.U.; Saenphet, K. Antiproliferative effect of Moringa oleifera Lam. and Pseuderanthemum palatiferum (Nees) Radlk extracts on the colon cancer cells. J. Med. Plants Res. 2012, 6, 139-145.

41. Berkovich, L.; Earon, G.; Ron, I.; Rimmon, A.; Vexler, A.; Lev-Ari, S. Moringa oleifera aqueous leaf extract down-regulates nuclear factor-kappaB and increases cytotoxic effect of chemotherapy in pancreatic cancer cells. BMC. Complement. Altern. Med. 2013, 13, 212-218. [CrossRef] [PubMed]

42. Jung, I.L. Soluble extract from Moringa oleifera leaves with a new anticancer activity. PLoS ONE 2014, 9, e95492. [CrossRef] [PubMed]

43. Tiloke, C.; Phulukdaree, A.; Chuturgoon, A.A. The antiproliferative effect of Moringa oleifera crude aqueous leaf extract on cancerous human alveolar epithelial cells. BMC. Complement. Altern. Med. 2013, 13, $226-233$. [CrossRef] [PubMed]

44. Chuang, P.H.; Lee, C.W.; Chou, J.Y.; Murugan, M.; Shieh, B.J.; Chen, H.M. Antifungal activity of crude extracts and essential oil of Moringa oleifera Lam. Bioresour.Technol. 2007, 98, 232-236. [CrossRef] [PubMed] 
45. Oluduro, A.O. Evaluation of antimicrobial properties and nutritional potentials of Moringa oleifera Lam. leaf in South-Western Nigeria. J. Microbiol. 2012, 8, 59-67.

46. Oluduro, O.A.; Aderiye, B.I.; Connolly, J.D.; Akintayo, E.T.; Famurewa, O. Characterization and antimicrobial activity of 4-( $\beta$-D-glucopyranosyl-1 $\rightarrow$ 4-(-Lrhamnopyranosyloxy)-benzyl thiocarboxamide; a novel bioactive compound from Moringa oleifera seed extract. Folia Microbiol. 2010, 55, 422-426. [CrossRef] [PubMed]

47. Pandey, A.; Pandey, R.D.; Tripathi, P.; Gupta, P.P.; Haider, J.; Bhatt, S.; Singh, A.V. Moringa ioleifera Lam. (Sahijan)-a plant with a plethora of diverse therapeutic benefits: an updated retrospection. Med. Aromat. Plants 2012, 1, 101-108. [CrossRef]

48. Jabeen, R.; Shahid, M.; Jamil, A.; Ashraf, M. Microscopic evaluation of the antimicrobial activity of seed extracts of Moringa oleifera. Pak J. Bot. 2008, 40, 1349-1358.

49. Maheshwari, K.; Yadav, R.K.; Malhotra, J.; Dhawan, N.G.; Mohan, L. Fascinating nutritional, prophylactic, therapeutic and socio-economic reconcile attributable to drum stick tree (Moringa oleifera Lam.). Glob. J. Med. Res. B: Pharm. Drug Discov.Toxicol. Med. 2014, 14, 11-22.

50. Stohs, S.J.; Hartman, M.J. Review of the safety and efficacy of Moringa oleifera. Phytother. Res. 2015, 29, 796-804. [CrossRef]

51. Gupta, A.; Gautam, M.K.; Singh, R.K.; Kumar, M.V.; Rao, C.V.; Goel, R.K.; Anupurba, S. Immunomodulatory effect of Moringa oleifera Lam. extract on cyclophosphamide induced toxicity in mice. Indian J. Exp. Biol. 2010, 48, 1157-1160.

52. Rachmawati, I.; Rifai, M. In vitro immunomodulatory activity of aqueous extract of Moringa oleifera Lam. leaf to the CD4+, CD8+ and B220+ cells in Mus musculus. J. Exp. Life Sci. 2014, 4, 15-20. [CrossRef]

53. Ghasi, S.; Nwobodo, E.; Ofili, J. Hypocholesterolemic effects of crude extract of leaf of Moringa oleifera Lam. in high-fat diet fed Wistar rats. J. Ethnopharmacol. 2000, 69, 21-25. [CrossRef]

54. Jain, P.G.; Patil, S.D.; Haswani, N.G.; Girase, M.V.; Surana, S.J. Hypolipidemic activity of Moringa oleifera Lam. Moringaceae, on high fat diet induced hyperlipidemia in albino rats. Rev. Bras. Framacogn 2010, 20, 969-973. [CrossRef]

55. Mehta, J.; Shukla, A.; Bukhariya, V.; Charde, R. The magic remedy of Moringa oliferia-An overview. Int. J. Biomed. Adv. Res. 2011, 2, 215-227. [CrossRef]

56. Moyo, B.; Masika, P.; Hugo, A.; Muchenje, V. Nutritional characterization of Moringa (Moringa oleifera Lam.) leaves. Afr. J. Biotechnol. 2011, 10, 12925-12933.

57. Saini, R.K.; Manoj, P.; Shetty, N.P.; Srinivasan, K.; Giridhar, P. Relative bioavailability of folate from the traditional food plant Moringa oleifera L. as evaluated in a rat model. J. food Sci. Technol. 2016, 53, 511-520. [CrossRef]

58. Mabruk, A.A.; Talib, H.N.; Mohamed, M.A.; Alawad, A.H. A note on the potential use of moringa oleifera tree as animal feed, Hillat Kuku. J. Vet. Med. Anim. Produc. 2010, 1, 184-188.

59. Ogbe, A.O.; John, P.A. Proximate study, mineral and anti-nutrient composition of Moringa oleifera leaves harvested from Lafia, Nigeria: potential benefits in poultry nutrition and health. J. Microb. Biotechnol. Food Sci. 2012, 1296-1308.

60. Aye, P.; Adegun, M.K. Chemical composition and some functional properties of Moringa, Leucaena and Gliricidia leaf meals. Agric. Bio. J. North America 2013, 4, 71-77. [CrossRef]

61. Thurber, M.D.; Fahey, J.W. Adoption of Moringa oleifera to combat under-nutrition viewed through the lens of the "Diffusion of Innovations" theory. Ecol. Food Nutri. 2009, 48, 212-225. [CrossRef]

62. Razis, A.F.A.; Ibrahim, M.D.; Kntayya, S.B. Health Benefits of Moringa oleifera. Asian Pacific J. Cancer Preven. 2014, 15, 8571-8576. [CrossRef]

63. Olagbemide, P.T.; Alikwe, P.C. Proximate analysis and chemical composi-tion of raw and defatted Moringa oleifera kernel. Adv. Life Sci. Technol. 2014, 24, 92-99.

64. Ferreira, P.M.P.; Davi, F.F.; Jose, T.A.O.; Ana, F.U.C. Moringa oleifera: Bioactive compounds and nutritional potential. Rev. Nutr. 2008, 21, 431-437. [CrossRef]

65. Nouman, W.; Basra, S.M.A.; Siddiqui, M.T.; Yasmeen, A.; Gull, T.; Alcayde, M.A.C. Potential of Moringa oleifera L. as livestock fodder crop: a review. Turkish J. Agric. Forest. 2014, 38, 1-14. [CrossRef]

66. Moreki, J.C.; Gabanakgosi, K. Potential use of Moringa olifera in poultry diets. Global J. Anim. Sci. Resh. 2014, 2, 109-115.

67. AbouSekken, M.S.M. Performance, immune response and carcass quality of broilers fed low protein diets contained either Moringa oleifera leaves meal or its extract. J. Am. Sci. 2015, 11, 153-164. 
68. Briones, J.; Leung, A.; Bautista, N.; Golin, S.; Caliwag, N.; Carlos, M.A.; Guevarra, J.; Miranda, J.; Guevarra, J.K.; Pili, N.L.; et al. Utilization of Moringa oleifera Lam. in animal production. Acta Hortic. (International Symposium on Moringa) 2017, 1158, 54. [CrossRef]

69. Alabi, O.; Malik, A.; Ng'ambi, J.; Obaje, P.; Ojo, B. Effect of aqueous Moringa Oleifera (Lam) leaf extracts on growth performance and carcass characteristics of Hubbard broiler chicken. Brazilian J. Poult. Sci. 2017, 19, 273-280. [CrossRef]

70. Khan, I.; Zaneb, H.; Masood, S.; Yousaf, M.S.; Rehman, H.F.; Rehman, H. Effect of Moringa oleifera leaf powder supplementation on growth performance and intestinal morphology in broiler chickens. Anim. Physio. Anim. Nutri. 2017, 101, 114-121. [CrossRef]

71. Abdulsalam, S.; Yahaya, M.; Yakasai, M. Performance of broiler chickens fed on Moringa oleifera leaf meal supplemented poultry feed. Nigeria Agric.J. 2015, 46, 139-146.

72. Ebenebe, C.L.; Umegechi, C.O.; Nweze, B.O. Comparison of haematological parameters and weight changes of broiler chicks fed different levels of Moringa oleifera diet. Int. J. Agric. Biosci. 2012, 1, 23-25.

73. David, L.S.; Vidanarachchi, J.K.; Samarasinghe, K.; Cyril, H.W.; Dematawewa, C.M.B. Effects of Moringa oleifera based feed additives on the growth performance and carcass quality of broiler chicken. Tropical Agric. Resh. 2012, 24, 12-20. [CrossRef]

74. Gakuya, D.W.; Mbugua, P.N.; Kavoi, B.; Kiama, S.G. Effect of supplementation of Moringa oleifera leaf meal in broiler chicken Feed. Int. J. Poul. Sci. 2014, 13, 208-213. [CrossRef]

75. Ochi, E.; Elbushra, M.E.; Fatur, M.; Abubakr, O.; Ismail, H.A. Effect of morin (Moringa oleifera Lam) seeds on the performance and carcass characteristics of broiler chickens. J. Natural Sci. Resh. 2015, 5, 66-73.

76. Gadzirayi, C.T.; Masamha, B.; Mupangwa, J.F.; Washaya, S. Performance of broiler chickens fed on mature Moringa oleifera leaf meal as a protein supplement to soybean meal. Int. J. Poult. Sci. 2012, 11, 5-10. [CrossRef]

77. Ayssiwede, S.B.; Dieng, A.; Bello, H.; Chrysostome, C.A.A.M.; Hane, M.B.; Mankor, A.; Dahouda, M.; Houinato, M.R.; Hornick, J.L.; Missohou, A. Effects of Moringa oleifera (Lam.) leaves meal incorporation in diets on growth performances, carcass characteristics and economics results of growing indigenous Senegal chickens. Pak. J. Nutri. 2011, 10, 1132-1145. [CrossRef]

78. Olugbemi, T.S.; Mutayoba, S.K.; Lekule, F.P. Evaluation of Moringa oleifera leaf meal inclusion in cassava chip based diets fed to laying birds. Livest. Resh. Rural Develop. 2010, 22, 118.

79. Kakengi, A.M.V.; Kaijage, J.T.; Sarwart, S.V.; Mutayoba, S.K.; Shem, M.N.; Fujihara, T. Effect of Moringa leaf meal as a substitute for sunflower seed meal on performance of laying hens in Tanzania. Livest. Resh. Rural Develop. 2007, 19.

80. Abou-Elezz, F.; Sarmiento-Franco, L.; Santos-Ricalde, R.; Solorio-Sanchez, F. Nutritional effects of dietary inclusion of Leucaena leucocephala and Moringa oleifera leaf meal on Rhode Island Red hens' performance. Cuban J. Agri. Sci. 2011, 45, 163-169.

81. Rehman, H.; Zaneb, H.; Masood, S.; Yousaf, M.; Ashraf, S.; Khan, I.; Shah, M.; Khilji, M.; Rehman, H. Effect of Moringa oleifera Leaf powder supplementation on pectoral muscle quality and morphometric characteristics of tibia bone in broiler chickens. Brazilian J. Poult. Sci. 2018, 20, 817-824. [CrossRef]

82. Nkukwana, T.T.; Muchenje, V.; Masika, P.J.; Hoffman, L.C.; Dzama, K. The effect of Moringa oleifera leaf meal supplementation on tibia strength, morphology and inorganic content of broiler chickens. South Af. J. Anim. Sci. 2014, 44, 228-239. [CrossRef]

83. Nkukwana, T.T.; Muchenje, V.; Pieterse, E.; Masika, P.J.; Mabusela, T.P.; Hoffman, L.C.; Dzama, K. Effect of Moringa oleifera leaf meal on growth performance, apparent digestibility, digestive organ size and carcass yield in broiler chickens. Livest. Sci. 2014, 161, 139-146. [CrossRef]

84. Nkukwana, T.T.; Muchenje, V.; Masika, P.J.; Hoffman, L.C.; Dzama, K.; Descalzo, A.M. Fatty acid composition and oxidative stability of breast meat from broiler chickens supplemented with Moringa oleifera leaf meal over a period of refrigeration. Food Chem. 2014, 142, 255-261. [CrossRef]

85. Safa, M.A.; Tazi, E. Effect of feeding different levels of Moringa oleifera leaf meal on the performance and carcass quality of broiler chicks. Int. J. Sci. Resh. 2014, 3, 147-151.

86. Portugaliza, H.P.; Fernandez, T.J. Growth performance of Cobb broilers given varying concentrations of malunggay (Moringa oleifera lam.) aqueous leaf extract. J. Anim. Feed Resh. 2012, 2, 465-469.

87. Zanu, H.K.; Asiedu, P.; Tampuori, M.; Abada, M.; Asante, I. Possibilities of using Moringa (Moringa oleifera) leaf meal as a partial substitute for fishmeal in broiler chickens diets. J. Anim. Feed Resh. 2012, 2, 70-75. 
88. Naji, T.A.; Amadou, I.; Abbas, S.; Zhao, R.Y.; Shi, Y.H.; Le, G.W. Phytosterol supplementation improves antioxidant enzymes status and broiler meat quality. Pak. J. Food Sci. 2013, 23, 163-171.

89. Zhang, C.; Yang, L.; Zhao, X.; Chen, X.; Wang, L.; Geng, Z. Effect of dietary resveratrol supplementation on meat quality, muscle antioxidative capacity and mitochondrial biogenesis of broilers. J. Sci. Food Agric. 2017, 98, 1216-1221. [CrossRef]

90. Falowo, A.B.; Fayemi, P.O.; Muchenje, V. Natural antioxidants against lipid-protein oxidative deterioration in meat and meat products: A review. Food Res. Intern. 2014, 64, 171-181. [CrossRef]

91. Voemesse, K.; Teteh, A.; Nideou, D.; N'nanlé, O.; Tété-Benissan, A.; Oke, O.; Gbeassor, M.; Decuypere, E.; Tona, K. Chemical composition and some functional properties of Moringa, Leucaena and Gliricidia leaf meals. European J. Poult. Sci. 2019, 83, 1-12.

92. Abouz-Elezz, F.M.K.; Sarmiento-Franco, L.; Santos-Ricalde, R.; Solorio-Sanchez, J.F. The nutritional effect of Moringa oleifera fresh leaves as feed supplement on Rhode Island Red hen egg production and quality. Tropical Anim. Health Prod. 2011, 44, 1035-1040.

93. Melesse, A.; Tiruneh, W.; Negesse, T. Effects of feeding Moringa stenopetala leaf meal on nutrient intake and growth performance of Rhode Island Red chicks under tropical climate. Trop. Subtrop. Agroeco. 2011, 14, 485-492.

94. Mabusela, S.P.; Nkukwana, T.T.; Mokoma, M.; Muchenje, V. Layer performance, fatty acid profile and the quality of eggs from hens supplemented with Moringa oleifera whole seed meal. South Af. J. Anim. Sci. 2018, 48, 234-243. [CrossRef]

95. Ahmad, S.; Khalique, A.; Pasha, T.N.; Mehmood, S.; Hussain, K.; Ahmad, S.; Shaheen, M.; Naeem, M.; Shafiq, M. Effect of Moringa oleifera (Lam.) pods as feed additive on egg antioxidants, chemical composition and performance of commercial layers. South Af. J. Anim. Sci. 2017, 47, 864-873. [CrossRef]

96. Lu, W.; Wang, J.; Zhang, H.J.; Wu, S.G.; Qi, G.H. Evaluation of Moringa oleifera leaf in laying hens: Effects on laying performance, egg quality, plasma biochemistry and organ histopathological indices. Italian J. Anim. Sci. 2016, 15, 658-665. [CrossRef]

97. Mahfuz, S.; Hui, S.; Zongjun, L. Improved production performance and health status with winter mushroom stem (Flammulina velutipes ) in laying chicken-A review. Int. J. Poult. Sci. 2017, 16, 112-117. [CrossRef]

98. Ma, Z.; Zhang, C.; Gao, X.; Cui, F.; Zhang, J.; Jia, M.; Jia, S.; Jia, L. Enzymatic and acidic degradation effect on intracellular polysaccharide of Flammulina velutipes SF-08. Int. J. Biologic. Macromol. 2015, 73, 236-244. [CrossRef]

99. Pathakoti, K.; Goodla, L.; Manjunath, M.; Tencomnao, T. Metabolic Alterations and the Protective Effect of punicalagin against glutamate-induced oxidative toxicity in HT22 cells. Neurotox. Res. 2017, 31, 521-531. [CrossRef]

100. Lavanya, G.; Manjunath, M.; Kavitha, P.; Thanasekaran, J.; Jeon-Rong, S.; Mike, F.; Paul, B.T.; Parthasarathy, R.P. Protective effects of ammannia baccifera against CCl4-induced oxidative stress in rats. Int. J. Environ. Res. Public Health 2019, 16, 1440.

101. Paguiaa, H.M.; Paguiab, R.Q.; Balbac, C.; Floresd, R.C. Utilization and evaluation of Moringa oleifera L. as poultry feeds. Biosci. Biotechnol. Biochem. 2014, 8, 343-347. [CrossRef]

102. Lurling, M.; Beekman, W. Anticyanobacterial activity of Moringa oleifera seeds. J. Applied Phycol. 2010, 22, 503-510. [CrossRef] [PubMed]

(C) 2019 by the authors. Licensee MDPI, Basel, Switzerland. This article is an open access article distributed under the terms and conditions of the Creative Commons Attribution (CC BY) license (http://creativecommons.org/licenses/by/4.0/). 